\title{
SFRP4 Gene
}

National Cancer Institute

\section{Source}

National Cancer Institute. SFRP4 Gene. NCI Thesaurus. Code C24804.

This gene plays a role in signal transduction, apoptosis and cell proliferation. 